Received: August 15, 2016

Research Article

\title{
The Health Cooperative Perception Scale: Development and Validation
}

\author{
Sait Söyler ${ }^{1}$ \\ Trakya University
}

\author{
Ayşegül Yıldırım Kaptanoğlu² \\ Trakya University
}

\begin{abstract}
The cooperative movement has a long history and is quite a widespread business style these days. As the cooperative movement develops, many different cooperatives have been established such as consumer cooperatives, agricultural cooperatives, and housing cooperatives. Health cooperatives have also been established to provide equity in and improve access to health services. In spite of having a deep-rooted history, health cooperatives are uncommon in Turkey. Only one health cooperative is found in Turkey, and the health cooperative movement should be supported here. Therefore, this study aims to develop a valid and reliable scale for measuring perceptions about health cooperatives. Accordingly, the researchers have constructed a 21-item scale. After conducting factor analysis, the scale was reduced to 15 statements. Validity and reliability analyses have also been performed. According to these analyses, the developed scale has high consistency and is a valid and reliable measuring tool.
\end{abstract}

\section{Keywords}

Cooperatives $\bullet$ Health $\bullet$ Health cooperatives $\bullet$ Scale development $\bullet$ Validity $\bullet$ Reliability

\footnotetext{
1 Correspondence to: Sait Söyler, Health Management Department, Faculty of Health Sciences, Trakya University, Edirne Turkey. Email: saitsoyler@trakya.edu.tr

2 Health Management Department, Faculty of Health Sciences, Trakya University, Edirne Turkey. Email: jessica.wagner@siemens.com

Citation: Söyler, S., \& Yıldırım Kaptanoğlu, A. (2017). The Health Cooperative Perception Scale: Development and validation. Sanitas Magisterium, 3, 53-59. http://dx.doi.org/10.12738/SM.2017.1.0032
} 
The International Labor Organization (ILO) defines cooperatives as "democratically governed autonomous communities that are jointly owned and managed to meet the economic, social, and cultural needs and objectives for which people come together voluntarily. Cooperatives are based on the values of solidarity, self-responsibility, equality, and honesty" (ILO, 2002). Members decide on a cooperative's theme, activities, and aims, and a cooperative is formed to meet the needs and objectives of their members (Koopmans, 2006). Cooperatives differ from corporations in many aspects. Firstly, cooperatives may make profits just like corporations and other kinds of companies, but this profit is distributed to shareholders as a return (also called surplus) according to the rate of their transactions within the cooperative, not in proportion to their capital. The management structure of cooperatives also differs from other kinds of companies. Each member of the cooperative can participate in management and cast a vote, while management in companies and corporations is centralized and distributed according to one's share of the capital. Many more differences are found between cooperatives and corporations, but the two mentioned above are the most important (Geray, 2014). The cooperative movement dates back centuries and is widely recognized. Although the modern cooperative movement is considered to date back to the Rochdale Society of Equitable Pioneers in 1844, quite a few organizations resemble cooperatives. People have known the importance of collaboration and tend to work together to achieve common objectives. Therefore, the method of doing business as a cooperative has become widespread. Customer, agricultural, worker, housing, and other kinds of cooperatives have come into force side by side (Birchall, 1997). In 1995 at the 31st Congress of the International Cooperatives Association in the United Kingdom, the cooperative principles accepted up to that day were reaffirmed and seven cooperative principles were adopted that are still valid (Hanson, 2004). Accordingly, these principles (Autry \& Hall, 2009; Mendoza \& Castillo, 2006) are:

- Voluntary and Open Membership

- Democratic Member Control

- Member's Economic Participation

- Autonomy and Independence

- Education, Training, and Information

- Cooperation among Cooperatives

- Concern for Community

The first principle, voluntary and open membership, means anybody can be a member of a cooperative, and being a member should be a voluntary decision. The second principle means that each member has rights in managing the cooperative. 
In unit cooperatives, each individual has one vote, and the cooperative is governed by a democratic approach in the upper organization. The third principle indicates that members have to pay for their share in the partnership. Cooperatives are a business model established by people who come together for common purposes and unaffiliated with any other institution. This gives autonomy and independence to cooperatives. A cooperative provides education and training opportunities to its members, representatives, employees, and managers in order to increase the cooperative's efficiency and development. Cooperatives cooperate with other coops and must strive to achieve collective benefits and sustainable development in accordance with their adopted policies.

Health cooperatives were introduced to the field of health in Denmark in 1904. After a little while, cooperatives were used in the struggle against malaria in India. In 1921, a cooperative was established in Yugoslavia to provide general health services. The first cooperative hospital was in operation in 1929. Health cooperatives developed rapidly during the 20th century, being established by health care workers to provide health insurance and services and by consumers to obtain health services, especially in rural areas. Established health-care cooperatives went on to become major organizations in 1996 by establishing the International Health Cooperative Organization (Shaffer, 1999).

Today, health cooperatives represent a large fraction of the healthcare sector around the world. For example, health cooperatives in Brazil have a relatively large share in the health care system. There are 848 health cooperatives in the country. When examining these cooperatives operating in Brazil, Unimed draws attention. Unimed consists of 354 cooperatives and 110,000 physicians (Girard, 2014).

The health cooperative movement is in its infancy in Turkey, with only one health cooperative founded in 2013 by specialist practitioners. Therefore, this movement requires much greater effort and should be understood well. Accordingly, this study's importance is in developing a scale that is useful for measuring perceptions about health cooperatives.

\section{Purpose}

Although the health cooperative movement expands day by day, no measurement tool is currently found in the literature for measuring perceptions about health cooperatives. Therefore, this study aims to develop a valid and reliable scale that measures these perceptions. 


\section{Method}

\section{Data Collection Tool}

The researchers composed the scale, which was used and tested, based on expert opinions and previous studies. As such, the first scale consisting of 21 statements was created as a four-point Likert-type scale ranging from "1 = Strongly Disagree" to " 4 = Strongly Agree." After conducting validity, reliability, and factor analyses, the number of the scale's statements was reduced to 15 .

\section{Universe and Sampling}

The universe of the study consists of all primary healthcare staff currently working in Edirne province and the districts of Edirne City in Turkey. At the time of the study, Edirne has 204 health workers. A stratified sampling method of 50\% was used for the sample. Accordingly, a total of 104 health personnel (family practitioners and nurses) have been included in the study.

\section{Data Collection}

The study was conducted voluntarily. After being informed in person, scales were distributed to the participants. Those who volunteered to participate were included, and those who refused to participate were excluded. The scale contains no personal statements or questions. After collection, the scales were transferred into SPSS Statistics 13.0. All analyses have been conducted using this program.

\section{Results}

The program, SPSS Statistics 13.0, was used to determine the scale's factor structure. Descriptive statistics were first calculated. According to these descriptive statistics, $75 \%$ of participants are female and $25 \%$ are men; $50 \%$ are family practitioners and the other $50 \%$ are nurses. Participants' mean age is $38.82(S D=8.34)$. Participants' mean work experience is 17.34 years. After determining the participants' descriptive statistics, validity, reliability, and factor analyses were conducted in the study. To measure the adequacy of the sample, the Keiser- Meyer-Olkin measure of sampling adequacy was calculated and found to be 0.773 . This value indicates that the sample is adequate for performing factor analysis. Therefore, explanatory factor analysis (EFA) was performed. According to this analysis, six statements with factor weights under 0.40 were excluded (Statements 3, 8, 10, 11, 13, and 17). After the first factor analysis, the scale remained with 15 statements under one factor, and EFA was performed again. The Keiser- Meyer-Olkin measure of sampling adequacy was found to be 0.841 for the second factor analysis. According to the second EFA, one factor explains $46.04 \%$ of the total variance. The scree plot is shown in Figure 1. 


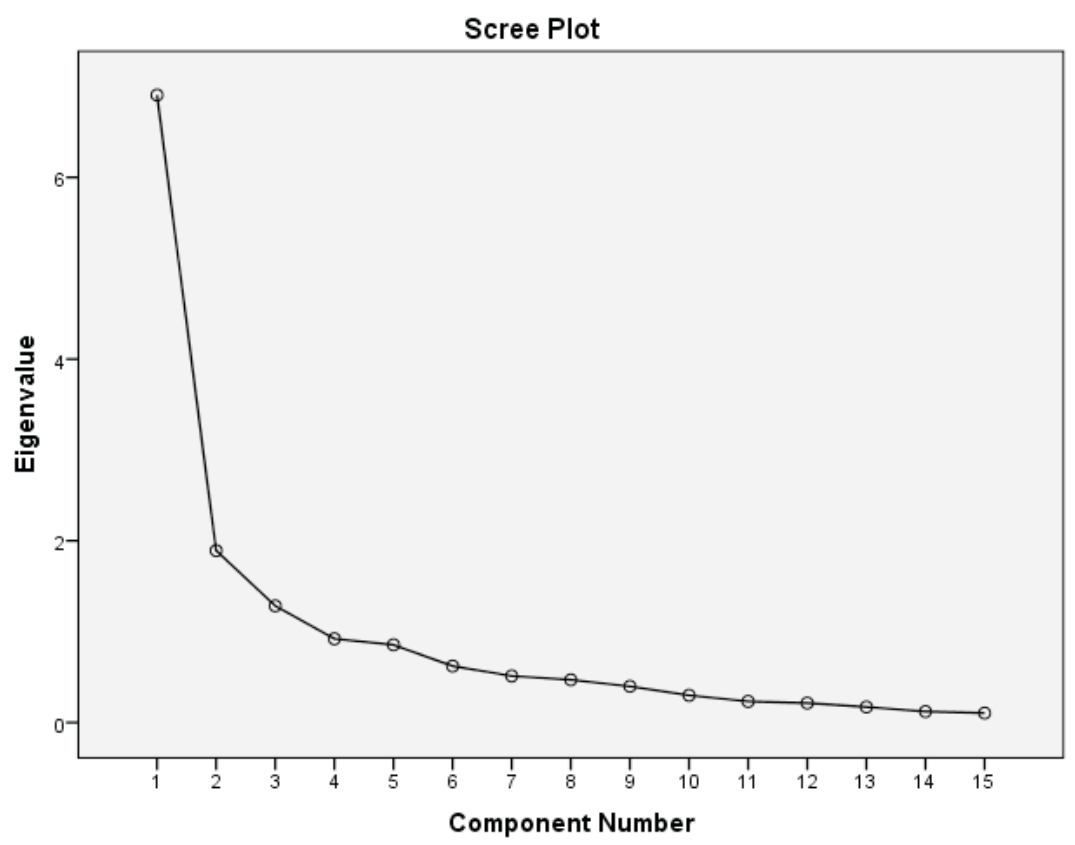

Figure 1. Scree plot.

\section{Each statement's factor weight is shown in Table 1.}

Table 1

Each Statement's Factor Weight

\begin{tabular}{lc}
\hline \multicolumn{1}{c}{ Statement } & Weight \\
\hline 1. Family physicians and nurses' practice of creating a cooperative provides high patient satisfaction. & 0.844 \\
2. Family physicians and nurses can have higher incomes by establishing a cooperative. & 0.804 \\
3. Family healthcare centers (FHC) gain financial and strategic strength by forming regional and & 0.809 \\
central unions. & 0.504 \\
4. Anyone can be a member of a health cooperative. & 0.583 \\
5. When FHCs are organized as a cooperative, each member has equal rights. \\
6. There is no need for cooperatives to be based on family physicians and nurses. \\
7. In the future, family physicians and nurses are going to need to cooperate with other family \\
physicians and nurses. \\
8. FHCs can provide less expensive goods if they organize as cooperatives that work with pharmacy & 0.689 \\
and consumer co-ops. & 0.435 \\
9. Not only can family physicians and nurses themselves benefit from establishing cooperatives, so & 0.749 \\
can their colleagues. & 0.855 \\
10. Working with a cooperative opens up new ideas by strengthening communication. \\
11. People who work more in a cooperative earn more income. \\
12. If FHCs are organized as cooperatives, they can attract more patients by making agreements & 0.582 \\
with insurance cooperatives. & 0.462 \\
13. FHCs can benefit from cooperative education, training, and information. \\
14. Co-ops have social responsibility. \\
15. If FHCs become cooperative, mutual benefits can be provided by making patients co-op \\
members. & 0.548 \\
\hline
\end{tabular}


Reliability analysis was conducted using these statements that remained. The split-half method was used to measure the scale's reliability. Reliability statistics are shown in Table 2.

Table 2

Reliability Results

\begin{tabular}{|c|c|c|}
\hline \multirow[t]{5}{*}{ Cronbach’s Alpha } & Part 1 & .859 \\
\hline & Part 2 & .816 \\
\hline & Correlation between forms & .798 \\
\hline & Spearman-Brown coefficient & .888 \\
\hline & Guttman split-half coefficient & .883 \\
\hline
\end{tabular}

According to the split-half method's results, Cronbach's alpha for the first part is 0.859 and 0.816 for the second part. This indicates the scale has high reliability. A positive and strong correlation exists between the two forms. The Spearman-Brown coefficient is considered good when it approaches 1 . As one can see in Table 3, the Spearman-Brown coefficient is high at 0.888 , and the Guttman split-half coefficient is high at 0.883 .

\section{Conclusion}

The health cooperative movement also has a long history. These cooperatives recognize the importance of an advanced upper organization and comprise the International Health Cooperative Organization. However, health cooperatives are an uncommon business style in the Turkish health system. Only one health cooperative exists in Turkey. Related to this, the Turkish Ministry of Customs and Trade has declared that health cooperatives will become important very soon. Therefore, this study aims to develop a scale that can measure health workers' perceptions about health cooperatives. According to the validity and reliability analyses, the developed 15-item scale is a valid and reliable measurement tool for determining perceptions about health cooperatives.

\section{References}

Autry, T., \& Hall, R. F. (2009). The law of cooperatives. Chicago, IL: American Bar Association.

Birchall, J. (1997). The international co-operative movement. Manchester, UK: Manchester University Press.

Geray, C. (2014). Kooperatifçilik [The cooperative system]. Ankara, Turkey: Nika Yayıncılık.

Girard, J. P. (2014, October). Better health and social care: How are coops and mutual boosting innovation and access worldwide? Paper presented at the International Summit of Cooperatives in Quebec, Canada. Retrieved from http:/www.fundacionespriu.coop/wp-content/uploads/ Report_LPS_Vol1.pdf 
Hanson, M. J. (2004). Legal framework of cooperative development. In C. D. Merrett \& N. Walzer (Eds.), Cooperatives and local development: Theory and applications for the 21st century (pp. 21-70). New York, NY: M. E. Sharpe.

International Labour Organization. (2002). Recommendation 193. Retrieved from http://www.ilo. org/dyn/normlex/en/f?p=NORMLEXPUB:12100:0::NO::P12100_ILO_CODE:R193

Koopmans, R. (2006). Starting a cooperative: Farmer-controlled economic initiatives. Wageningen, Netherlands: Agromisa Foundation and CTA.

Mendoza, E. V., \& Castillo, E. T. (2006). The path to the success of cooperatives. Quezon, Philippines: UP Press.

Shaffer, J. (1999). Historical dictionary of the cooperative movement. London, UK: Scarecrow Press. 
